\title{
New Jersey's Abbott Districts: Education Finances during the Great Recession
}

\author{
Rajashri Chakrabarti and Sarah Sutherland
}

\begin{abstract}
Funding for New Jersey's low-income school districts tumbled in the most recent recession, and the Abbott districts - a group of poor urban districts that for almost two decades received special appropriations from the state-were hit especially hard. A comparison with the state's other low-income districts reveals that the Abbott districts faced markedly sharper declines in aid, relative to trend. Consequently, while all of the low-income districts responded to the drop in state aid by scaling back spending on support services and utilities, only the Abbott group also made significant cuts in instructional spending. Moreover, the fiscal strains of recession appear to have led to layoffs of untenured teachers in the Abbott districts, but not in the state's other low-income districts.
\end{abstract}

\begin{abstract}
uring the 2009 and 2010 school years, three developments converged to dramatically reshape education finances in New Jersey's low-income school districts. ${ }^{1}$ First, the onset of the Great Recession significantly weakened the fiscal condition of the state and local governments, providers of most education funding. ${ }^{2}$ Second, the passage of the American Recovery and Reinvestment Act (ARRA) made $\$ 2.2$ billion available for education spending in New Jersey in the 2010 school year. $^{3}$ Third, New Jersey's School Funding Reform Act of 2008 (SFRA) eliminated the special funding that since 1990 had been extended to a particular group of low-income districts known as the Abbott districts.
\end{abstract}

How did these developments, on net, affect the level of school funding in New Jersey's low-income districts? And how did these districts adjust their instructional and non-instructional expenditures in response to the changes in their revenues? In this issue of Second District Highlights, we compare how three groups of low-income districts coped with the funding cutbacks and appropriations of the period. We give particular attention to the Abbott districts, which comprise 20 percent of all students enrolled in the state's public schools, receive roughly 50 percent of the state's funds,

\section{Second District Highlights}

\footnotetext{
${ }^{1}$ Throughout this article, we refer to school years by the year corresponding to the spring semester.

${ }^{2}$ Local, state, and federal governments finalize their budgets in the spring prior to the budgeted year. More specifically, the budgets for the 2008 school year were finalized in the spring of 2007, before the recession officially began (December 2007, as calculated by the National Bureau of Economic Research) and before decision makers were aware of the impending recession. Therefore, 2008 is considered pre-recession in our analysis, and 2009 is taken as the first year budgets were directly affected by recession. See Deitz, Haughwout, and Steindel (2010) for more information about the recession's impact on the state budgets of New York and New Jersey.

${ }^{3}$ See Orr and Sporn (2012) for more information about ARRA spending in New York and New Jersey.
} 
and have been the subject of an unprecedented series of courtroom battles over funding issues. In addition, we consider two benchmark groups: the rural, low-income "Bacon districts" and a set of districts, located in different parts of the state, whose income profile almost exactly matches that of the Abbott districts.

Our analysis reveals that the Abbott districts experienced considerably sharper declines - relative to trend-in both total revenue and total expenditure than the other low-income groups in the wake of the recession. Moreover, while the other groups of low-income districts avoided cuts in instructional spending - the spending category considered most relevant for student learning — the Abbott districts' total revenues fell sufficiently deeply that no spending category, including instructional spending, was preserved. Finally, it appears that in the Abbott districts, the fiscal strains of recession may have led to reductions in the number of untenured teachers; no evidence of such retrenchment exists for the other two groups.

\section{Background}

\section{The Abbott and Bacon Districts' Role in New Jersey's}

\section{Education History}

The varying outcomes observed across New Jersey's low-income districts invite particular attention because of the state's ongoing efforts to ensure equal education opportunities for all of its students. The New Jersey Constitution states that any child between the ages of five and eighteen has the constitutional right to a "thorough and efficient" education. ${ }^{4}$ Long before the start of the most recent recession, the meaning of these words had been a topic of much public and legal debate. In the 1973 Robinson $v$. Cahill ruling, the state supreme court declared that New Jersey's school funding system had failed to meet the state constitution's requirement of providing a thorough and efficient education for elementary- and secondary-school students. ${ }^{5}$ Much like the court orders to follow, this ruling was based on discrepancies in per pupil spending within the state's school districts.

New Jersey enacted the 1975 Public School Education Act to address these discrepancies, but concerns relating to funding inequities between wealthy and low-income school districts persisted. ${ }^{6}$ The Abbott v. Burke lawsuit, filed in 1981 on behalf of a group of students from four New Jersey school districts, charged that funding disparities prevented children in poor urban districts from receiving an adequate education. ${ }^{7}$ In 1985 , the court ruled in favor of the plaintiffs, finding that wealthy districts

\footnotetext{
${ }^{4}$ New Jersey State Constitution. Article VIII, Taxation and Finance, Section IV, 1947. See http://www.njleg.state.nj.us/lawsconstitution/constitution.asp.

${ }^{5}$ For more information on this ruling, see Tractenberg (1974).

${ }^{6}$ For additional information on the 1975 Public School Education Act and the history of education in New Jersey, see New Jersey Department of Education (2001).

${ }^{7}$ Our discussion of the Abbott litigations draws on information presented on the Education Law Center webpage "The History of Abbott v. Burke," available at http://www.edlawcenter.org/cases/abbott-v-burke/abbott-history.html.
}

Table 1

\section{Portion of Revenues Received by the Thirty-One Abbott Districts}

\begin{tabular}{lcc} 
Spring Term & Percentage of Total State Aid & Percentage of Total Federal Aid \\
\hline 1999 & 45.1 & 39.7 \\
2000 & 46.2 & 39.9 \\
2001 & 47.1 & 42.3 \\
2002 & 49.8 & 40.9 \\
2003 & 49.3 & 42.2 \\
2004 & 49.6 & 40.5 \\
2005 & 51.0 & 42.0 \\
2006 & 51.2 & 41.6 \\
2007 & 49.7 & 41.3 \\
2008 & 49.4 & 41.6 \\
2009 & 49.9 & 41.0 \\
2010 & 50.0 & 37.6 \\
\hline
\end{tabular}

Source: Authors' calculations, using the New Jersey Department of Education's Audit Summary data.

spent 40 percent more than poor districts. In its ruling, the court expanded the number of school districts covered by the litigation to twenty-eight - a group that came to be known as the Abbott districts.

The resulting mandate required an immediate and significant increase in funding to these districts (Resch 2006). ${ }^{8}$ The court case, and the related court cases that followed, changed the way school districts were funded in New Jersey. In fact, by the start of the 1999 school year (the time our data set begins), the designated Abbott districts—-then thirty-one in number-received 45 percent of the total state aid funds distributed to all 572 districts. This share increased to 51 percent by 2005 and remained at 50 percent as of 2010 (Table 1).

A separate series of court cases involving perceived inequities in education funding was initiated in 1997 by lawyers representing the Bacon districts-sixteen low-income districts in rural areas of New Jersey. The plaintiffs argued that the state had given special treatment to the Abbott districts because of their low-income, urban status. The Bacon districts were also impoverished, the plaintiffs maintained, and their rural status should not have prevented them from receiving the same treatment as their urban counterparts. Unlike the Abbott court cases, the Bacon litigation did not lead to additional funding for its districts. Instead, the court ruled that each district faced a unique set of circumstances, and while the Bacon districts were "no less deserving" than the Abbott districts, the solution was for the Department of Education to reexamine the entire education finance system. In the words of the court, it "[was] time to abandon [the state's]

\footnotetext{
${ }^{8}$ Three districts have since been added to the Abbott group, bringing the total number of districts to thirty-one as of this writing.
} 
reliance on money as a surrogate for either education equity or adequacy." ${ }^{\text {"T }}$ This reexamination led to a new funding system known as the School Funding Reform Act of 2008, which we discuss in more detail below.

\section{Recession and Federal Stimulus}

School finances came under significant pressure during the 2007 recession, when the nation's state and local governments-providers of the vast majority of education funding — experienced substantial fiscal stress. ${ }^{10}$ The downturn in housing prices, employment, income, and business activity contributed to smaller tax revenues and larger budget gaps. As a result, state and local governments were unable to maintain the same level of support for New Jersey's schools as in the past.

To mitigate the pressure on school finances, Congress passed the American Recovery and Reinvestment Act of 2009, an economic stimulus package that provided $\$ 840$ billion in new spending, with $\$ 100$ billion designated for public education. ${ }^{11}$ Districts were directed to use the ARRA funds to save and create jobs, to boost student achievement, and to bridge gaps in achievement across students. The requirements specified that 82 percent of the stabilization funds in education go toward the support of public education, and that states restore for fiscal years 2009, 2010, and 2011 a level of support for public education equal to the greater of the fiscal year 2008 or fiscal year 2009 level.

Of the total $\$ 100$ billion assigned to public education nationally, New Jersey received $\$ 2.2$ billion. ${ }^{12}$ The largest portion of New Jersey's appropriation was used to implement the state's education funding formula, and almost all of the funds were spent in the 2010 school year.

\section{School Funding Reform Act}

The School Funding Reform Act, backed by New Jersey Governor Jon Corzine and approved by the state legislature in January 2008, also had significant effects on education financing. The SFRA formula called for a 7 percent increase in state funding for K-12 education in the 2009 school year but, for the first time since 1990, did not earmark funds solely for Abbott districts. ${ }^{13}$ Instead, a uniform formula was applied to all districts, with the division of

\footnotetext{
${ }^{9}$ See http://caselaw.findlaw.com/nj-superior-court-appellate-division/1225307 .html\#footnote_7. This court ruling was made in January 2006.

${ }^{10}$ See Deitz, Haughwout, and Steindel (2010).

${ }^{11}$ Our discussion of the American Recovery and Reinvestment Act of 2009 is based on data presented at http://www.recovery.gov.

12 The $\$ 2.2$ billion figure is derived from a document provided by the State of New Jersey Department of Treasury, Office of Management and Budget, in February 2012. It represents the total appropriation for New Jersey under the American Recovery and Reinvestment Act.

${ }^{13}$ See the New Jersey Department of Education webpage "School Funding Reform Act of 2008," available at http://nj.gov/education/sff.
}

funds determined by the portion of low-income students and the number of students requiring special education in each district.

In response to this new legislation, the Abbott plaintiffs again challenged the New Jersey education formula, disputing its constitutionality as defined in past cases. In May 2009, however, the New Jersey Supreme Court upheld the state's new education funding system, ruling unanimously that it did indeed satisfy the constitutional requirements for thorough and efficient education. According to the New Jersey Department of Education, school funding in the 2009 school year met the new SFRA requirements, and budgets were prepared for the 2010 school year using the formula. However, midway through 2010, the recession began to place significant strains on education finances. Revenue streams were projected to be $\$ 2.2$ billion lower than what was necessary to cover the state's budget deficit, making reductions in education funding highly likely.

New Jersey's constitution requires the state to maintain a balanced budget, so education funding was cut significantly midyear. The funding caps for district aid were lowered, and many districts received less state aid than budgeted and less aid than required under the SFRA formula.

This 2010 midyear budget reduction brought New Jersey back to the courtroom, with the Education Law Center arguing on behalf of the Abbott districts. In March 2011, the New Jersey Supreme Court issued an opinion that the state had yet again failed in its constitutional requirements and ordered a remedy payment of $\$ 500$ million to the Abbott districts. The Court's order applied only to the thirty-one Abbott districts; the remaining districts, wealthy or otherwise, did not receive a re-appropriation following the midyear cuts of the 2010 school year. ${ }^{14}$

\section{Post-Recession Changes in Education Finances}

To assess how the Abbott districts fared in the wake of the recession, we compare them with other low-income districts that did not face the same withdrawal of earmarked funds. Our comparison groups are the Bacon districts and all non-Abbott districts falling within the lowest 10 percent of the income distribution (here termed the "non-Abbott low-income districts"). Our measure of income is the percentage of each district's students who are eligible for free or reduced-price lunches. By this measure, our second comparison group comprises non-Abbott districts whose share of students eligible for free or reduced-price lunches in the immediate pre-recession period (2008 school year) fell within the bottom decile of the income distribution.

Summary demographic and socioeconomic characteristics for the Abbott, Bacon, and non-Abbott low-income districts are

\footnotetext{
${ }^{14}$ Since our data set continues only to the 2010 school year, this post-2010 re-appropriation is not captured in our analysis.
} 
Table 2

\section{Demographic Summary Statistics}

\begin{tabular}{lccc} 
& $\begin{array}{c}\text { Abbott } \\
\text { Districts }\end{array}$ & $\begin{array}{c}\text { Bacon } \\
\text { Districts }\end{array}$ & $\begin{array}{c}\text { Non-Abbott Low- } \\
\text { Income Districts }\end{array}$ \\
\hline $\begin{array}{l}\text { Students on free/reduced-price } \\
\text { lunch (percent) }\end{array}$ & 65.53 & 43.66 & 64.62 \\
$\begin{array}{l}\text { Male students (percent) } \\
\text { Student racial composition (percent) }\end{array}$ & 51.20 & 51.76 & 51.90 \\
$\quad$ White & 21.42 & 59.57 & 43.77 \\
$\quad$ Black & 36.74 & 19.44 & 21.65 \\
$\quad$ Hispanic & 39.63 & 17.00 & 30.33 \\
$\quad$ Asian & 1.92 & 2.48 & 3.70 \\
\hline $\begin{array}{l}\text { Students per school district } \\
\text { Percentage of total state } \\
\text { enrollment in 2008 }\end{array}$ & 8,771 & 1,707 & 1,409 \\
\hline
\end{tabular}

Source: Authors' calculations, using the New Jersey Department of Education's Enrollment Data Reports.

Notes: The data shown are averages for the 2008 school year. Students per school district is based on the average daily enrollment for students "on roll" in the groups' districts. Total state enrollment refers to the number of students enrolled in the 572 districts in our data set. Charter districts, nonoperating districts, and districts that receive students via tuition only are not included in our analysis.

presented in Table 2. While the non-Abbott low-income districts closely match the Abbott districts in terms of the percentage of students on free or reduced-price lunches, the Bacon districts are less poor than the Abbott districts. Both groups of comparison districts (and especially the Bacon districts) are relatively more white and less black and Hispanic than the Abbott districts.

Our analysis examines how the three groups of low-income districts were affected by the recession and the subsequent developments we described earlier - that is, the ARRA stimulus funding and the introduction of SFRA, the new funding formula. ${ }^{15}$ Specifically, we ask: How did each group's level of education funding change? And how did the district groups adjust their expenditures in response to these changes? Thus, we study the patterns in the 2009 and the 2010 school years and analyze how they diverged from trends existing before these changes (see Box 1 for a description of our empirical analysis).

In interpreting the results for 2009, recall that this was the first time since 1990 in which the state aid formula did not earmark funds specifically for Abbott districts that exceeded those granted to the other districts. Therefore, not only did the Abbott districts share the negative effects of the Great Recession faced by all New Jersey districts in 2009, but they also faced a second negative shock in the form of the SFRA. Accordingly, the 2009 effects in

\footnotetext{
${ }^{15}$ Our analysis is based on a rich panel data set that we constructed from multiple sources. The data set embraces the school years 1999-2010 and combines annual school-district-level data from the New Jersey Department of Education's Office of School Finance, the National Center for Education Statistics' School Finance Survey (F-33) and Common Core of Data, as well as data from the U.S. Census Bureau.
}

Box 1

\section{Empirical Strategy}

To explore how the Abbott, Bacon, and non-Abbott low-income districts' education funding and expenditures changed in association with the three key developments of 2009 and 2010, we conduct a trend shift analysis. The motivation behind this methodology is that school finances would be expected to continue to grow at the pre-2009 trend in the absence of the recession, the ARRA stimulus funding, and the introduction of SFRA. Thus, the effects of these events are captured by any shifts from this pre-2009 trend in the 2009 and 2010 school years. Our results are based on the following regression, which we estimate separately for each of the three groups of districts using data from 1999 to 2010:

$$
Y_{i t}=f_{i}+\alpha_{1} T+\alpha_{2} v_{1}+\alpha_{3} v_{2}+\alpha_{4} X_{i t}+e_{i t}
$$

where $Y_{i t}$ represents each school finance variable of school district $i$ in year $t$. These school finance variables include total expenditure per pupil, total revenue per pupil, federal aid per pupil, state aid per pupil, local revenue per pupil, property tax revenue per pupil, instructional expenditure per pupil, instructional support per pupil, student services per pupil, transportation per pupil, student activities per pupil, utilities and maintenance per pupil, median teacher salary, median teacher years of experience, and total number of teachers. The variable $T$ represents the time trend and takes a value of 0 in the immediate pre-recession year (2008); it increases by one for each subsequent year and declines by one in each previous year. School district fixed effects are denoted by $f_{i}$; $X_{i t}$ denotes controls for racial composition and poverty level (percentage of students eligible for free and reduced-price lunches) of the district. The variable $v_{1}=1$ if the year $\geq 2009$ and 0 otherwise; $v_{2}=1$ if the year $\geq$ 2010 and 0 otherwise.

The coefficient $\alpha_{1}$ represents the overall trend in the corresponding financial variable during the pre-recession period (from 1999 up to and including the 2008 school year). The coefficients of interest are $\alpha_{2}$, representing the intercept shift at the onset of the recession, and $\alpha_{3}$, representing the additional intercept shift during the federal stimulus period. The shift relative to pre-existing trends in 2009 and 2010 is captured by $\alpha_{2}$ and $\left(\alpha_{2}+\alpha_{3}\right)$, respectively. All regressions include district-level fixed effects, $f_{i}$, and control for the demographic and socioeconomic composition of the district. The results are robust to the inclusion and exclusion of these covariates.

this article capture a combination of two factors: the impact of the recession and the effect of eliminating the special assignment of funds to the Abbott districts. While we cannot differentiate the effects of these two factors, our analysis sheds light on how the Abbott districts responded to declines in revenues by adjusting their spending on various non-instructional and instructional categories. The results provide information on the districts' priorities for spending categories in times of fiscal stress.

In 2010, all districts received a positive shock from the ARRA federal stimulus and a negative shock when the deepening recession induced a reduction in state funding midway through the 
school year. ${ }^{16}$ With the negative impact to state aid funding, we would expect a dampening effect on the positive shock from the ARRA federal stimulus. Note, however, that these cuts came only midyear and did not affect schools' planned budgets or their expenditure in the first half of the school year. Any positive additional effects in 2010 (over 2009 effects) can be regarded as underestimates of the stimulus effect, while additional negative effects in 2010 may mean that the recession effects dominated that year.

\section{Interpreting the Shifts from Pre-Recession Trends}

The results of our empirical analysis can best be conveyed in graphic form. In Chart 1, the top panel plots the time series for a variable from the revenue side (state aid per pupil); the bottom panel, the time series for a variable from the expenditure side (instructional expenditure per pupil). The solid lines represent actual data; the dashed blue line in the top panel shows the pre-recession trend for Abbott state aid based on data in 2008 and earlier; the dotted blue line represents the trend in the post-recession period as predicted by the pre-recession trend. The intercept shifts in 2009 and 2010 (from the empirical strategy box: $\alpha_{2}$ and $\left[\alpha_{2}+\alpha_{3}\right]$, respectively) are represented in the top panel. As the chart shows, the intercept shifts refer to the gap between what we would expect to see based on the prerecession trend and what actually occurred in 2009 and 2010.

For both 2009 and 2010, the top panel shows a larger decline in state aid per pupil (relative to pre-existing trends) in the Abbott districts than in either the Bacon or the non-Abbott low-income districts. Similarly, the bottom panel shows a steeper decline (again, relative to pre-existing trends) in instructional expenditure per pupil in the Abbott districts than in the Bacon and non-Abbott low-income districts. In fact, the direction of growth in the Bacon and non-Abbott districts is noticeably positive in 2009 and 2010.

To provide a better idea of the size of the effects and to simplify comparisons between shifts in the various financial variables, we compute percentage shifts in addition to the actual shifts captured by the coefficients described in the box on the preceding page $\left(\alpha_{2}\right.$ and $\left.\left[\alpha_{2}+\alpha_{3}\right]\right)$. We do so by expressing the shift coefficients as percentages of the pre-recession (2008) base of the corresponding financial variable. ${ }^{17}$ In our discussion, we focus on the percentage shift immediately following the recession (in 2009) and the percentage shift in 2010 (computed by expressing the sum of the two effects $\alpha_{2}$ and $\alpha_{3}$ from our regression as a percentage of the pre-recession base in 2008). The latter shift

\footnotetext{
${ }^{16}$ Recall that midway through the 2010 school year, the funding caps for district aid were cut, and many districts received less state aid than budgeted and less aid than required under the School Funding Reform Act formula.

${ }^{17}$ Recall that governments finalize their budgets in the spring prior to the budgeted year. The budgets for the 2008 school year were finalized in the spring of 2007, before decision makers were aware of the impending recession. For this reason, 2009 is taken as the first year budgets were directly affected by the recession, and 2008 is considered pre-recession.
}

Chart 1

\section{Time Series of Reported Data Compared with Trend}
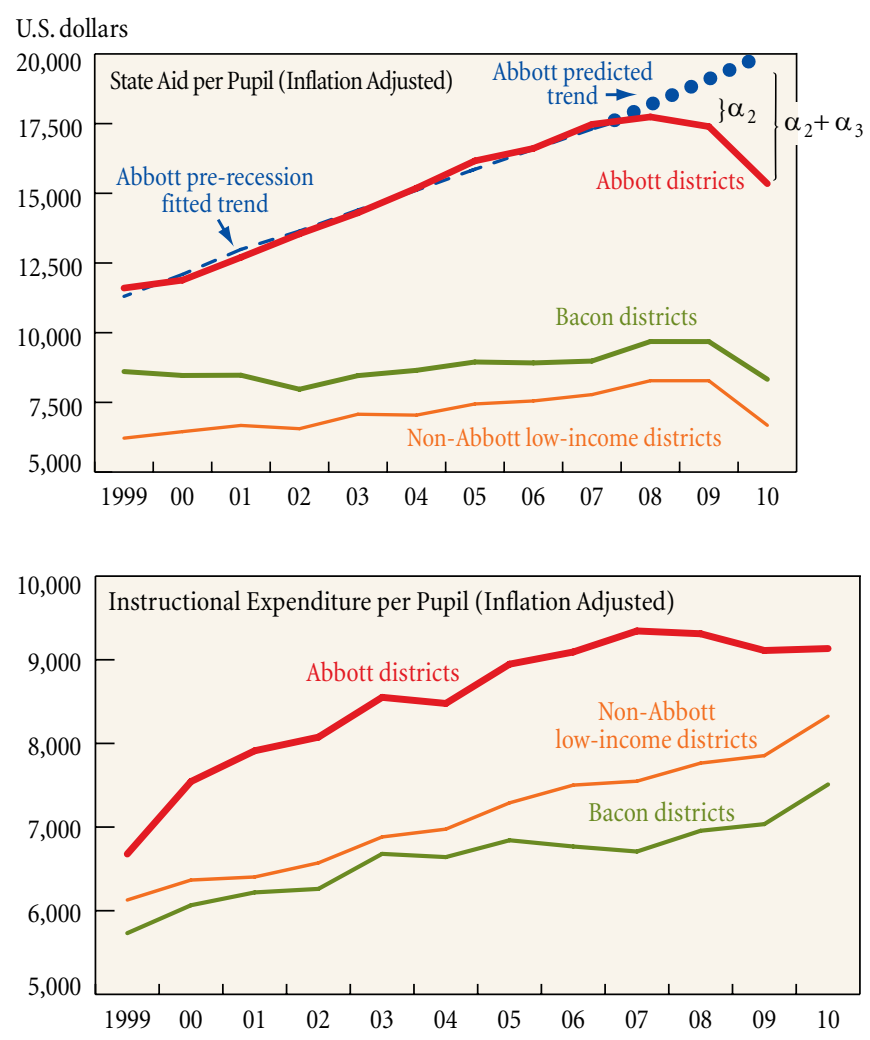

Source: Authors' calculations, using the New Jersey Department of Education's Audit Summary and Taxpayers' Guide to Education Spending.

captures the combined effects of the recession, the new SFRA formula, and the federal stimulus in 2010.

To highlight the post-recession patterns, we present these percentage shifts in histogram-style charts (Charts 2 and 3). The green bars represent changes from the pre-recession trend in 2009 expressed as a percentage of the pre-recession base; the blue bars indicate changes from the pre-recession trend in 2010 expressed as a percentage of the pre-recession base.

\section{Changes in Revenue}

Relative to pre-existing trends, both total revenue and total expenditure showed considerably sharper declines in the Abbott districts than in the non-Abbott low-income districts and the Bacon districts in 2009 and 2010 (Chart 2). Consistent with our understanding of the midyear cuts to the state aid funding formula, Chart 2 shows sharp downward shifts in state aid per pupil in 2010 in all three groups of districts, and for the Abbott districts, the decline is considerably larger than seen in 2009. The shifts in both 2009 and 2010 are much more prominent in the Abbott districts and differ from those of the other two groups of 
Chart 2

Shifts in Overall Expenditure, Revenue, and Funding Sources per Pupil
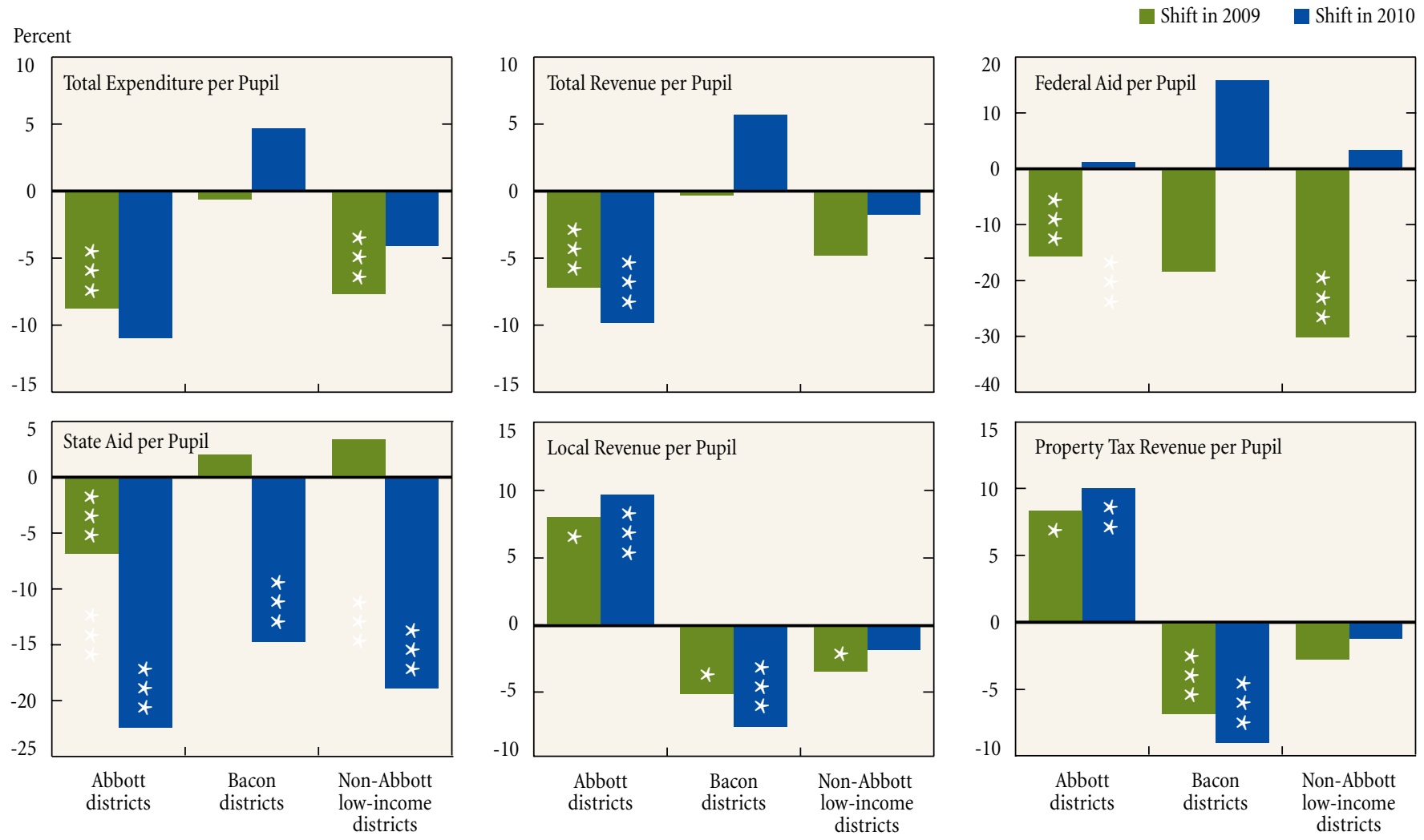

Source: Authors' calculations, using the New Jersey Department of Education's Audit Summary and Taxpayers' Guide to Education Spending.

* Significant at the 10 percent level.

$* *$ Significant at the 5 percent level.

$\star * *$ Significant at the 1 percent level.

districts significantly. For example, the 22.4 percent drop in state aid expenditure for the Abbott districts in 2010 translates to a $\$ 3,363$ reduction per pupil from what would have been expected in 2010 on the basis of the pre-recession trend; the corresponding reductions in per pupil expenditure for the Bacon and nonAbbott low-income districts were $\$ 1,291$ and \$1,564, respectively. This finding corroborates expectations that the elimination of the earmarked funds for the Abbott districts would decrease the revenues of these districts above and beyond the statewide reductions in aid. Although the ARRA stimulus led to positive shifts in federal aid per pupil for all of the district groups in 2010, the upturn in the Abbott districts was by far the smallest.

The patterns for property taxes and local revenue also exhibit distinct heterogeneity. Unlike the other two district groups (as well as the rest of the state), ${ }^{18}$ the Abbott districts showed a significant upward shift in property taxes and local revenue in both years, suggesting that property taxes were raised in these

\footnotetext{
${ }^{18}$ The results for the rest of the state are available on request.
}

districts as a method of compensating for the substantial decline in state aid. ${ }^{19}$ However, in interpreting this finding, one should note that the pre-recession property tax revenue per pupil in the Abbott districts was considerably lower than in the Bacon and non-Abbott low-income districts: Abbott districts received an average of $\$ 3,012$ per pupil in property tax revenue, compared with $\$ 6,708$ in Bacon districts and \$10,442 in non-Abbott lowincome districts. Hence, even a comparatively small increase in property tax revenue per pupil in the Abbott districts shows up as a large percentage shift from pre-recession levels.

No evidence exists of any significant shift in the number or composition of the students in each group of low-income districts after the recession. Thus, the patterns identified here are not generated by changes in student composition or student movement. ${ }^{20}$

\footnotetext{
${ }^{19}$ While property taxes - as of the 2012 school year — can no longer legally be increased to make up for state aid loss, such increases were legal in both 2009 and 2010.

${ }^{20}$ Empirical results are available upon request.
} 

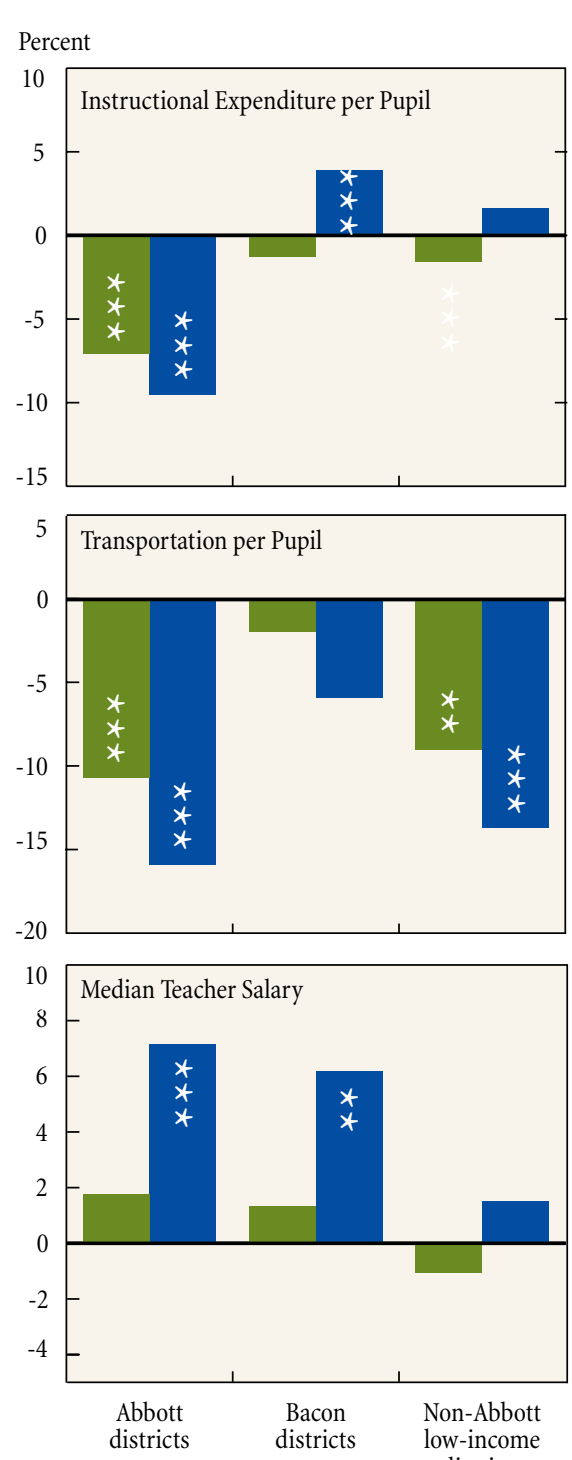
districts
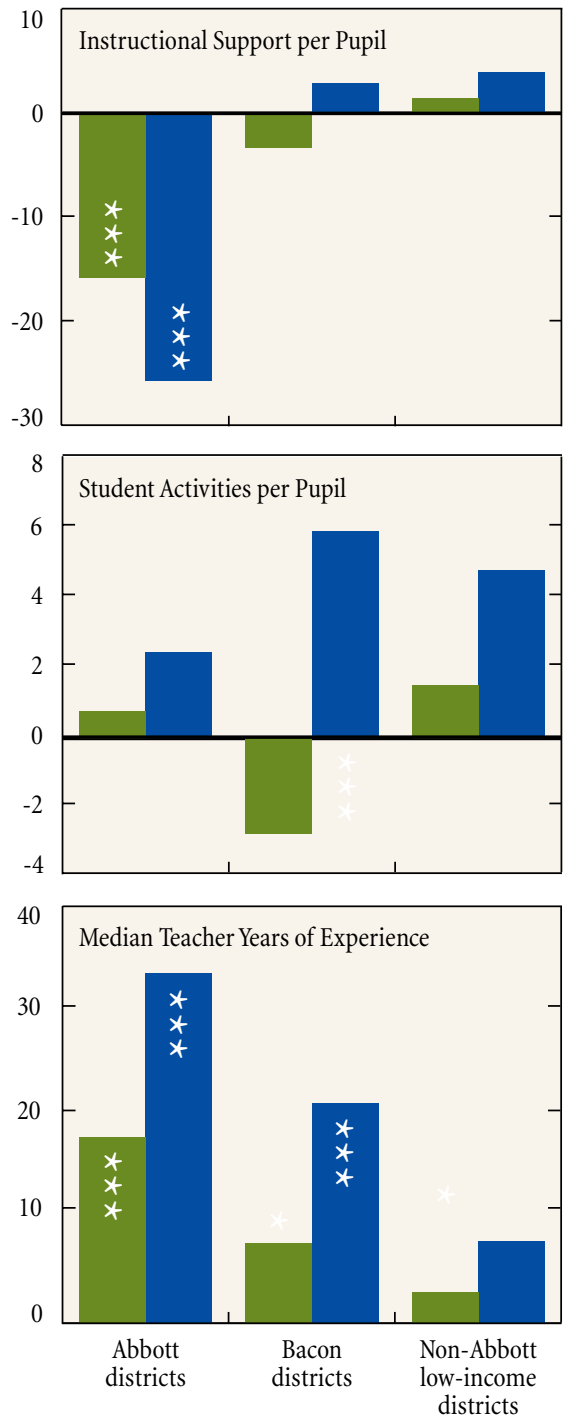

Shift in 2009

Shift in 2010
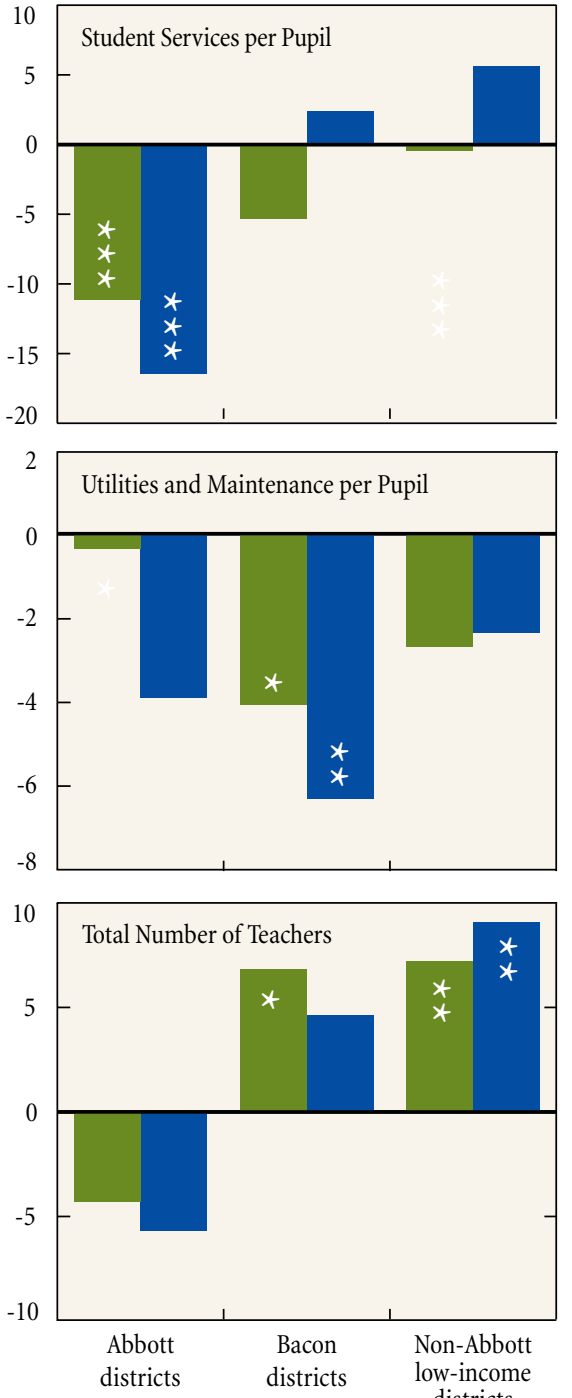

Source: Authors' calculations, using the New Jersey Department of Education's Audit Summary, Taxpayers' Guide to Education Spending, and Report Card data.

* Significant at the 10 percent level.

** Significant at the 5 percent level.

$\star * *$ Significant at the 1 percent level.

\section{Compositional Changes in Expenditure Categories}

Given the reductions in school revenue, we now look at how the low-income districts prioritized their spending in 2009 and 2010. Chart 3 breaks out the various components of school expenditures (see Box 2 for definitions), shedding light on the spending patterns in the three groups of districts following the recession. Our findings are striking. Across nearly all variables, both instructional and non-instructional, the Abbott districts showed the largest declines and the smallest increases in spending, rela- tive to pre-recession trends. The Bacon districts, facing smaller declines in state and federal aid than the other two low-income groups, maintained spending across the board at higher levels than their counterparts did. ${ }^{21}$

The breakout of expenditures in Chart 3 also provides strong evidence that all three groups of districts shifted spending away

\footnotetext{
21 The only exception is expenditure on utilites; the Bacon districts faced the
} largest declines in this category. 
Box 2

\section{Definitions of Expenditure Components}

\author{
Instructional Expenditures \\ All expenditures associated with direct classroom instruction: teacher \\ salaries and benefits; classroom supplies.
}

\section{Instructional Support}

All support service expenditures designed to assess and improve students' well-being: food services, educational television, library, and computer costs.

\section{Student Services}

Psychological and health services; school store.

\section{Utilities and Maintenance}

Heating, lighting, water, and sewage; operation and maintenance.

\section{Transportation}

Total expenditure on student transportation services.

\section{Student Activities}

Co-curricular activities: physical education, publications, clubs, and band.

from non-instruction categories such as instructional support services, student services, transportation, and utilities and maintenance in order to preserve instructional spending. Instructional spending, which includes teacher salaries and classroom expenditures, is considered to be the category most directly related to student learning. It appears that when faced with revenue depletions, districts quite reasonably shifted funds typically reserved for non-instructional services to the more critical category of classroom spending.

Many of the spending decisions in the non-instruction categories were made at the local level. For example, while no statewide statute called for a decrease in transportation costs, local districts reportedly took it upon themselves to cut expenses such as the transport-on a courtesy basis - of students who did not live far enough from their school for busing to be mandatory. Actions of this kind were one way in which localities were able to exercise discretion and preserve spending on higher-priority educational needs during a time of financial strain.

In the case of the Abbott districts, however, scaling back spending on non-instruction services did not fully offset the need to reduce instructional outlays. While the Abbott districts exhibited smaller percentage declines in instructional expenditure than in the non-instruction categories, our results still show significant reductions in instructional spending in both 2009 and 2010 relative to pre-existing trends - a pattern not seen in the other two groups (Chart 3). Indeed, the declines in instructional expenditure per pupil for the Abbott districts are substantially larger than those recorded for the other groups. The nearly 10 percent downward shift in instructional expenditure for the Abbott districts in 2010 corresponds to a $\$ 663$ reduction per pupil from what would have been expected in 2010 based on the pre-recession trend; by contrast, the Bacon districts saw an increase of $\$ 272$ and the non-Abbott low-income districts an increase of $\$ 129$ in the same category. Also of note is that the 2010 declines for the Abbott districts coincided with an influx of ARRA stimulus funds, indicating that the extra funds could not reverse the double negative shock of the recession and the new SFRA formula. Overall, these results suggest that while the other two district groups seemed to have succeeded in averting significant cuts in instructional expenditure, the Abbott districts' revenues declined so deeply that nearly all categories were reduced.

One further result of our breakout of expenditures merits attention. Of the three district groups, the Abbott districts showed the largest upward shift in median teacher salary in both years following the onset of the recession. As Chart 3 shows, this shift was associated with a key change in teacher composition. In addition to recording the steepest increase in teacher salaries, the Abbott districts also witnessed the largest increases in median teacher experience following the recession. The 33 percent upturn in median years of experience for the Abbott districts corresponds to an increase of three years of median teaching experience relative to what would have been expected in 2010 based on the pre-existing trend.

There are a few explanations for this noteworthy change. First, the range for median years of experience in 2008 is very tight (between six and fifteen) and the base level is small (nine years of experience), so even a small change translates to a large percentage increase. Second, the pre-existing trend for this variable was negative (equivalent to a decline of roughly one year of experience per year), and 2009 was the very first year in our data in which this negative trend reversed. Thus, an increase of only one year in the actual data between 2008 and 2010 appears as a large shift (three years) from the pre-existing negative trend. Finally, at the time, state law provided tenure to teachers who completed three consecutive years, making it very difficult for schools to lay off teachers with more than three years of experience barring evidence of serious misconduct. ${ }^{22}$ Since there was no increase in the number of teachers following the recession in the Abbott districts (Chart 3, last row), the patterns in median teacher salary and median years of experience suggest that the tighter budget conditions faced by the Abbott districts prompted them to shed their untenured teachers. ${ }^{23}$

\footnotetext{
22 The tenure requirement was changed to four years in 2012.

${ }^{23}$ Many news articles cited the unprecedented number of layoff warning notices, known legally as "Rice" notices, which mostly targeted untenured, less experienced teachers following the recession. For example, see Chris Neidenberg, "Teachers and Union Leaders Blast Jersey City's Proposed Layoffs," Jersey City Independent, May 31, 2011.
} 


\section{Conclusion}

Spending in New Jersey's school districts took a hit in the most recent recession, and the Abbott districts-low-income urban districts that until recent years received special funding from the state-were no exception. Our analysis shows that shifts in both federal and state aid were less favorable for the Abbott districts than for two comparison groups: the rural, low-income Bacon districts and a set of districts whose income profile almost exactly matched that of the Abbott group. The Abbott districts experienced the smallest increase in federal funding relative to existing trends, and their reductions in state aid exceeded those faced by the state's other low-income districts in both 2009 and 2010. Local aid for the Abbott districts did show a significant upturn in 2009, an increase most likely explained by the districts' heavier reliance on higher property taxes in the face of fiscal constraints. The Bacon districts, coping with more moderate declines in state and federal aid, maintained spending almost across the board at higher levels than the other groups.

The largest differences uncovered in our analysis related to the composition of school expenditures. The two comparison groups were able to maintain spending (again, relative to existing trends) in the instructional expenditures category - the category considered to be the most directly related to student learning. In sharp contrast, the Abbott districts showed both economically and statistically significant declines in instructional expenditures in both 2009 and 2010. Most noteworthy, they were the only group that, in spite of the influx of stimulus funds, saw a large downturn in instructional spending in 2010. In all groups of districts, non-instructional categories such as student services, transportation, and instructional support saw larger declines than did the instructional categories, but these declines were by far the deepest in the Abbott districts.

The authors thank Joydeep Roy, Amy Ellen Schwartz, Leanna Stiefel, and seminar participants at the New York University-Federal Reserve Bank of New York Fiscal Breakfast for their valuable insights and feedback. They are grateful to Kevin Dehmer, Susan Ecks, Frank Lavdas, and the New Jersey Department of Education for patiently answering numerous questions and providing generous help in acquiring the data. They also thank staff at the U.S. Census Bureau, the U.S. Department of Education, and the New Jersey School Boards Association for answering many questions and providing assistance with different components of the data.

\section{References}

Deitz, Richard, Andrew F. Haughwout, and Charles Steindel. 2010."The Recession's Impact on the State Budgets of New York and New Jersey." Current Issues in Economics and Finance 16, no. 6 (June-July).

New Jersey Department of Education. 2001. Public Education in New Jersey. Available at http://www.nj.gov/education/genfo/penj.pdf.

Orr, James, and John Sporn. 2012."The American Recovery and Reinvestment Act of 2009: A Review of Stimulus Spending in New York and New Jersey." Current Issues in Economics and Finance 18, no. 6

Resch, Alexandra M. 2006. “The Effects of the Abbott School Finance Reform on Student Achievement in New Jersey." Public Economics Papers.

Tractenberg, Paul L. 1974. “Robinson v. Cahill: The 'Thorough and Efficient' Clause." Law and Contemporary Problems 38, Winter: 312-32. Available at http:// scholarship.law.duke.edu/lcp/vol38/iss3/4.

\section{ABOUT THE AUTHORS}

Rajashri Chakrabarti is an economist in the Regional Analysis Function of the Federal Reserve Bank of New York; Sarah Sutherland is a senior research analyst in the Bank's Macroeconomic and Monetary Studies Function.

The content co-editor of this article is Wilbert van der Klaauw.

Current Issues in Economics and Finance is published by the Research and Statistics Group of the Federal Reserve Bank of New York. Linda Goldberg and Thomas Klitgaard are the editors of the series.

Editorial Staff: Valerie LaPorte, Michelle Bailer, Karen Carter, Mike De Mott, Anna Snider

Production: Jane Urry, Jessica lannuzzi, David Rosenberg

Back issues of Current Issues are available at http://www.newyorkfed.org/research/current_issues/.

The views expressed in this article are those of the authors and do not necessarily reflect the position of the Federal Reserve Bank of New York or the Federal Reserve System. 


\section{RELATED READINGS FROM THE FEDERAL RESERVE BANK OF NEW YORK}

\section{The Liberty Street Economics Blog}

Available at http://libertystreeteconomics.newyorkfed.org/

Young Student Loan Borrowers Retreat from Housing and Auto Markets

Meta Brown and Sydnee Caldwell

April 17, 2013

Historical Echoes: 150 Years after the Morrill Act

Rajashri Chakrabarti, Amy Farber, and Basit Zafar

September 21, 2012

Soaring Tuitions: Are Public Funding Cuts to Blame?

Rajashri Chakrabarti, Maricar Mabutas, and Basit Zafar

September 19,2012

\section{Grading Student Loans}

Meta Brown, Andrew Haughwout, Donghoon Lee, Maricar Mabutas, and Wilbert van der Klaauw

March 5, 2012

How Colleges and Universities Can Help Their

Local Economies

Jaison R. Abel and Richard Deitz

February 13,2012

Tough Decisions, Depleted Revenues: New Jersey's Education Finances during the Great Recession

Rajashri Chakrabarti and Sarah Sutherland

February 1,2012

How Did the Great Recession Affect New York State's Public Schools?

Rajashri Chakrabarti and Elizabeth Setren

January 30, 2012

Unintended Consequences in School Accountability Policies

Rajashri Chakrabarti and Noah Schwartz

November 28, 2011

Are Charter Schools Draining Private School Enrollment?

Rajashri Chakrabarti, Joydeep Roy, and Elizabeth Setren

August 24, 2011

\section{Publications of the Research and Statistics Group}

Available at http://www.newyorkfed.org/research/publication _annuals/index.html

Unintended Consequences of School Accountability Policies: Evidence from Florida and Implications for New York

Rajashri Chakrabarti and Noah Schwartz

Economic Policy Review, vol. 19, no. 1, May 2013.

Over the past two decades, state and federal education policies have tried to hold schools more accountable for educating students by tying rewards and sanctions to test scores and other measurable outcomes. A common criticism of these policies is that they may induce schools to "game the system" along with—or instead of making genuine educational improvements. One such strategic response may be to classify low-performing students in categories that are excluded from grade computation in an effort to artificially inflate scores. This article analyzes school responses to an influential accountability-tied voucher program in Florida. The authors find evidence of increased classification into "excluded" categories in failing schools following the program's inception. Their findings have important implications for New York City's Progress Reports program and New York's implementation of the federal No Child Left Behind Act. While these policies were modeled after the Florida program, they contain important design differences that are likely to discourage this type of gaming, although they may encourage other strategic classifications.

The Role of Colleges and Universities in Building Local Human Capital

Jaison R. Abel and Richard Deitz

Current Issues in Economics and Finance, vol. 17, no. 6, 2011.

Colleges and universities can contribute to the economic success of a region by deepening the skills and knowledge - or human capital — of its residents. Producing graduates who join the region's educated workforce is one way these institutions increase human capital levels. In addition, the knowledge and technologies created through research activities at area universities may not only attract new firms to a region but also help existing businesses expand and innovate. These "spillover effects" can in turn raise the region's demand for high-skilled workers.

Agglomeration and Job Matching among College Graduates Jaison R. Abel and Richard Deitz Staff Reports, no. 587, December 2012

This paper considers one potential source of urban agglomeration economies: better job matching. Focusing on college graduates, the authors construct two direct measures of job matching based on how well an individual's job corresponds to his or her 


\section{RELATED READINGS FROM THE FEDERAL RESERVE BANK OF NEW YORK (CONTNUED)}

college education. Consistent with matching-based theories of urban agglomeration, their analysis yields evidence that larger and thicker local labor markets help college graduates find better jobs by raising both the likelihood and quality of a match. The authors then assess the extent to which better job matching of college-educated workers increases individual-level wages and thereby contributes to the urban wage premium. While the findings suggest that college graduates with better job matches do indeed earn higher wages on average, the contribution of such job matching to aggregate urban productivity appears to be relatively modest.

\section{Mismatch Unemployment}

Aysegul Sahin, Giorgio Topa, Joseph Song, and Giovanni L. Violante Staff Reports, no. 566, August 2012

This study develops a framework where mismatch between vacancies and job seekers across sectors translates into higher unemployment by lowering the aggregate job-finding rate. The authors use this framework to measure the contribution of mismatch to the recent rise in U.S. unemployment by exploiting two sources of cross-sectional data on vacancies, JOLTS and HWOL, a new database covering the universe of online U.S. job advertisements. Mismatch across industries and occupations explains at most one-third of the total observed increase in the unemployment rate, whereas geographical mismatch plays no apparent role. The share of the rise in unemployment explained by occupational mismatch is increasing in the education level.

Precarious Slopes? The Great Recession, Federal Stimulus, and New Jersey Schools

Rajashri Chakrabarti and Sarah Sutherland

Staff Reports, no. 538, January 2012, revised September 2012

The authors exploit rich panel-data and trend-shift analysis to analyze how New Jersey school finances were affected during the Great Recession and the ARRA federal stimulus period. Their study finds strong evidence of downward shifts in both revenue and expenditure following the recession. Federal stimulus seemed to have helped in 2010; however, both revenue and expenditure still declined. While total revenue fell, the various components of revenue did not witness symmetric changes. The infusion of funds under the federal stimulus occurred simultaneously with statistically and economically significant cuts in state and local financing. The study also shows a compositional shift in expenditures in favor of categories that are linked most closely to instruction, while several non-instruction categories, including transportation and utilities, declined. Interestingly, budgetary stress seems to have led to significant layoffs of untenured teachers, leading to a rightward shift of the teacher salary and experience distributions. Heterogeneity analysis shows that high-poverty and urban districts sustained the largest falls in the post-recession era.
Housing Markets and Residential Segregation: Impacts of the Michigan School Finance Reform on Inter- and Intra-district Sorting

Rajashri Chakrabarti and Joydeep Roy

Staff Reports, no. 565, August 2012

Local financing of public schools in the United States leads to a bundling of two distinct choices - residential choice and school choice- and is often thought to increase the degree of socioeconomic segregation across school districts. A school finance reform, aimed at equalization of school finances, can in principle weaken this link between housing choice and choice of schools. This study examines the impacts of the Michigan school finance reform of 1994 (Proposal A) on spatial segregation. The reform was a state initiative intended to equalize per pupil spending across Michigan school districts and to reduce the role of local financing. The authors find that Proposal A led to increases in the value of housing stock in the lowest-spending school districts and to improvements in several socioeconomic indicators in these districts, implying a decline in neighborhood sorting. We also find that the reform affected dispersion of incomes and educational attainment within school districts, boosting withindistrict heterogeneity in the lowest-spending school districts, while lowering it in the highest-spending districts. Still, demand for residence in the highest-spending communities remains strong, implying that even a comprehensive government aid program can fail to make a large impact on residential segregation.

\section{The Impact of the Great Recession on School District Finances: Evidence from New York \\ Rajashri Chakrabarti and Elizabeth Setren Staff Reports, no. 534, December 2011}

Using detailed data on school finance indicators and an analysis of trend shifts, the authors examine how the Great Recession affected school funding in New York State. While they find no evidence of effects on either total revenue or total expenditure, they identify important compositional changes within both categories. On the revenue side, there is strong evidence of substitution of funds: the infusion of funds from the federal stimulus occurred simultaneously with statistically and economically significant cuts in state and local financing. On the expenditure side, instructional expenditure was maintained, while transportation, student activities, and utilities suffered. Important heterogeneities in experiences are also observed by poverty level, metropolitan area, school district size, and urban status. Affluent districts were hurt the most; the New York City metro area, especially Nassau County, sustained the largest losses in both revenue and expenditure. 